УДК 342.9

DOI https://doi.org/10.32837/pyuv.v0i2(27).207

\author{
M.I. Coф"ï \\ кандидат юридичних наук, \\ докторант \\ Науково-дослідного інституту публічного права
}

\title{
НАПРЯМИ ВДОСКОНАЛЕННЯ ДІЯЛЬНОСТІ ДЕРЖАВНИХ ОРГАНІВ У СФЕРІ РЕАЛІЗАЦІЇ ФІСКАЛЬНОЇ ПОЛІТИКИ В УКРАЇНІ
}

Належне функціонування всіх суспільних інституцій пов'язано із станом їх фінансування. Адже без фінансів існування держави як механізму управління суспільством неможливе. Державі фінансові ресурси необхідні не лише для власного функціонування держави, а і для забезпечення виконання нею своїх функцій [1, с. 122]. Належне фінансування відповідних суспільних інституцій стає можливим в результаті проведення ефективної фіскальної політики, що напряму залежить від діяльності суб'єктів, відповідальних за цей напрям роботи держави. Саме тому вдосконалення діяльності державних органів у сфері реалізації фіскальної політики в Україні слід розцінювати як одну з провідних організаційно-правових засад здійснення фіскальної політики держави в умовах Євроінтеграції. На жаль, сьогодні мову можна вести про значну кількість проблемних питань, пов'язаних з діяльністю державних органів в напряму реалізації фіскальної політики в Україні. Аналіз більшості 3 них вимагає проведення не одного наукового дослідження. А тому у нашій статті ми зосередимо увагу лише на основних з таких проблем.

Окремі проблемні питання діяльності державних органів у сфері реалізації фіскальної політики в Україні у своїх наукових дослідженнях розглядали такі вчені, як В.Л. Андрущенко, О.В. Зварич, Є.О. Балацький, Н.С. Педченко, С.В. Каламбет, В.Ю. Стрілець А.Л. Коломієць, І.Г. Лук'яненко, С.С. Мошкова, А.Д. Мельник та багато інших. Однак незважаючи на чималу кількість наукових розробок, в юридичній літературі відсутні комплексні дослідження, присвячені вдосконаленню діяльності державних органів у сфері реалізації фіскальної політики в Україні.

Саме тому мета статті - визначити ключові напрями вдосконалення діяльності державних органівусферіреалізаціїфіскальноїполітикив Україні.

Говорячи про проблеми діяльності державних органів щодо реалізації фіскальної політики, насамперед слід наголосити на особливостях законодавчого закріплення їх правового статусу. Як приклад слід зазначити, що правовий статус окремих з центральних органів виконавчої влади визначено на рівні двох, різних за своєю юридичною природою, нормативно-правових актів. Зокрема, правовий статус Міністерства фінансів України визначено Положенням «Про Міністерство фінансів України», що затверджено постановою Кабінету Міністрів України від 20 серпня 2014 року № 375 [2]. Водночас сьогодні й досі залишається чинним Положення «Про Міністерство фінансів України», що затверджено указом Президента України від 8 квітня 2011 року № 446/2011 [3]. Така ж сама ситуація прослідковується й щодо Міністерства економічного розвитку і торгівлі, правовий статус якого визначено в Положенні «Про Міністерство економічного розвитку і торгівлі», затвердженого постановою Кабінету Міністрів України від 20 серпня 2014 року № 459 [4], а також у Положенні «Про Міністерство економічного розвитку і торгівлі України», затвердженого указом Президента України від 31 травня 2011 року № 634/2011 [5]. Подібні недоліки нормативної регламентації правового статусу суб’єкта відповідних правових відносин прослідковуються й стосовно цілого ряду міністерств та інших центральних органів виконавчої влади.

Вищенаведена ситуація стала можливою внаслідок прийняття Закону України «Про відновлення дії окремих положень Конституції України" від 21 лютого 2014 року [6]. У результаті прийняття зазначеного нормативно-правового акта до Основного Закону України було внесено суттєві зміни, зокрема, ст. 116 було доповнено новим пунктом 9-1, відповідно до якого повноваженнями з утворення, реорганізації та ліквідації міністерств та інших центральних органів виконавчої влади було наділено Кабінет Міністрів України [7]. До внесення відповідних змін до Конституції України такими повноваженнями був наділений Президент України. Саме тому сьогодні правовий статус відповідного центрального органу виконавчої влади, в тому числі відповідального за реалізацією фіскальної політики в Україні, визначено на рівні положення, що затверджено указом Президента України, а також положення, затвердженого постановою Кабінету Міністрів України. Зважаючи на те, що згідно зі ст. 3 (правові засади діяльності міністерств, інших центральних органів виконавчої влади) Закону України «Про центральні органи виконавчої влади» міністерства інші центральні органи виконавчої влади в своїй 
діяльності керуються Конституцією України, іншими законами України, указами Президента України та постановами Верховної Ради України, прийнятими відповідно до Конституції та законів України, актами Кабінету Міністрів України, іншими актами законодавства України [8], наявний стан нормативної регламентації їх правового статусу слід вважати незадовільним. А тому, на нашу думку, вже давно назріла необхідність прийняття Президентом України указу, відповідно до якого свою чинність втрачають укази Президента України, якими було затверджено відповідні положення про міністерства та інші центральні органи виконавчої влади.

Говорячи про правовий статус центральних органів виконавчої влади, на яких чинним національним законодавством покладено завдання із реалізації фіскальної політики, слід вказати на те, що назва окремих з них не відповідає їх функціональному призначенню, що напряму суперечить законодавчим положенням. Яскравим прикладом вказаної проблеми функціонування державних органів у сфері реалізації фіскальної політики є законодавчі положення щодо закріплення правового статусу центрального органу виконавчої влади, відповідального за забезпечення формування та реалізацію державного фінансового контролю. Так, відповідно до Закону України «Про основні засади здійснення державного фінансового контролю в Україні» від 26 січня 1993 року здійснення державного фінансового контролю забезпечує центральний орган виконавчої влади, уповноважений Кабінетом Міністрів України на реалізацію державної політики в сфері державного фінансового контролю [9]. Слід відмітити, що до прийняття Закону України «Про внесення змін до деяких законодавчих актів України щодо діяльності Міністерства фінансів України, Міністерства економічного розвитку і торгівлі України, інших центральних органів виконавчої влади, діяльність яких спрямовується та координується через відповідних міністрів» від 16 жовтня 2012 року вищенаведений Закон України мав назву «Про державну контрольно-ревізійну службу в Україні» й відповідно визначав статус державної контрольно-ревізійної служби в Україні, її функції та правові основи діяльності [10]. Правовий статус Головного контрольно-ревізійного управління України було визначено на рівні Положення «Про Головне контрольно-ревізійне управління України», затвердженого постановою Кабінету Міністрів України від 27 червня 2007 року № 884 [11].

Указом Президента України «Про оптимізацію системи центральних органів виконавчої влади» від 9 грудня 2010 року № 1085/2010 шляхом реорганізації Головного контрольно-ревізійного управління України було створено Державну фінансову інспекцію України [12]. При цьому ука- зом Президента України від 23 квітня 2011 року № 499/2011 було затверджено Положення «Про Державну фінансову інспекцію України» [13]. У подальшому правовий статус Державної фінансової інспекції було визначено в постанові Кабінету Міністрів України «Питання Державної фінансової інспекції» від 7 вересня 2011 року № 968 [14], а також постанові Кабінету Міністрів України від 6 серпня 2014 року № 310, якою затверджено Положення «Про Державну фінансову інспекцію» [15]. Слід відмітити, що всі з названих вище нормативно-правових актів, на рівні яких визначено правовий статус Державної фінансової інспекції, й досі залишаються чинними, не дивлячись на те, що даний центральний орган виконавчої влади ще в 2015 році черговий раз було реорганізовано.

Так, відповідно до постанови Кабінету Міністрів України «Про утворення Державної аудиторської служби» від 28 жовтня 2015 року № 868 як центральний орган виконавчої влади було створено Державну аудиторську службу шляхом реорганізації Державної фінансової інспекції [16]. Правовий статус новоствореного центрального органу виконавчої влади як такого, що забезпечує формування та реалізує державну політку в сфері державного фінансового контролю, було визначено на рівні постанови Кабінету Міністрів України від 3 лютого 2016 року № 43, якою затверджено Положення «Про Державну аудиторську службу України» [17]. Як слідує з аналізу наведених законодавчих приписів, правовий статус Державної аудиторської служби України як центрального органу виконавчої влади, відповідального за забезпечення формування та реалізацію державної політики в сфері здійснення фінансового контролю, так само як і розглянутих вище центральних органів виконавчої влади, закріплено у вкрай неефективний спосіб. При цьому, якщо вести мову про особливості правового статусу Державної аудиторської служби, увагу слід звернути на нелогічність самої назви даного центрального органу виконавчої влади.

Закріплення в назві відповідного центрального органу виконавчої влади позначення того, що він, наприклад, є «службою», є не просто формальністю, а згідно з приписами чинного національного законодавства вказівкою на його основне функціональне призначення. Якщо проаналізувати приписи зазначеного вище Положення «Про Державну аудиторську службу України», побачимо, що про надання цим центральним органом виконавчої влади адміністративних послуг йдеться єдиний раз. Так, серед основних завдань Державної аудиторської служби України називається завдання із надання адміністративних послуг у передбачених законом випадках. Більшість же функцій Державної аудиторської служби це функції із здійснення фінансового контролю, що є ло- 
гічним з огляду на мету створення даного органу [17]. У такому разі, з урахуванням законодавчих положень, вказаний центральний орган виконавчої влади повинен бути створений як інспекція. Так, відповідно до приписів Закону України «Про центральні органи виконавчої влади», якщо більшість функцій центрального органу виконавчої влади складають контрольно-наглядові функції за дотриманням державними органами, органами місцевого самоврядування, їх посадовими особами, юридичними та фізичними особами актів законодавства, то центральний орган виконавчої влади утворюється як інспекція [8].

Окремо слід наголосити й на недоцільності використання в назві вищенаведеного центрального органу виконавчої влади такої категорії, як «аудит». Правові засади аудиторської діяльності визначено на рівні Закону України «Про аудит фінансової звітності та аудиторську діяльність» від 21 грудня 2017 року, відповідно до ст. 1 якого аудит фінансової звітності - аудиторська послуга з перевірки даних бухгалтерського обліку і показників фінансової звітності та/або консолідованої фінансової звітності юридичної особи або представництва іноземного суб'єкта господарювання, або іншого суб'єкта, який подає фінансову звітність і консолідовану фінансову звітність групи, 3 метою висловлення незалежної думки аудитора про їі відповідність у всіх суттєвих аспектах вимогам національних положень (стандартів) бухгалтерського обліку, міжнародних стандартів фінансової звітності або іншим вимогам. Проте, як зазначено в ч. 2 ст. 2 вищенаведеного нормативно-правового акта, його дія не поширюється на діяльність органів державної влади, їх підрозділів і посадових осіб, уповноважених законами України на здійснення державного фінансового контролю, а також на діяльність з внутрішнього аудиту юридичних осіб, органів державної влади й органів місцевого самоврядування [18].

Отже, аналіз наведених позицій свідчить про те, що правовий статус центрального органу виконавчої влади, відповідального за забезпечення формування та реалізацію діяльності в сфері здійснення фінансового контролю, на нормативно-правовому рівні врегульовано із значними недоліками. Такі недоліки знаходять свій прояв як у значній кількості нормативно-правових актів, на рівні яких закріплено правовий статус цього органу державної влади, так і в назві самого органу, що не відповідає ані його функціональному призначенню, ані змісту його діяльності. Враховуючи те, що здійснення фінансового контролю слід розцінювати як один 3 основних і найдієвіших засобів забезпечення фінансової дисципліни та стану законності в сфері мобілізації, розподілу та використання централізованих і децентралізованих фондів коштів, можна стверджувати, що поза його ефективним здійсненням належна реалізація фіскальної політики в Україні стає неможливою. А тому сьогодні вкрай потребує свого перегляду нормативна регламентація правового статусу Державної аудиторської служби України. I хоча слід підтримати позицію щодо того, що підзаконний рівень нормативно-правового регулювання порівняно з законами забезпечує набагато оперативніше реагування на динаміку потреб правового регулювання [19, с. 19-20], він все ж таки залишається менш стабільним, оскільки має більш спрощену процедуру прийняття відповідного нормативно-правового акта та внесення до нього відповідних змін. А тому, на нашу думку, вказаний вище центральний орган виконавчої влади повинен іменуватися, як і раніше, Державна фінансова інспекція із закріпленням її правового статусу на рівні відповідного Закону України.

У наведеному вище випадку йшлося про ще один суттєвий недолік функціонування органів державної влади в сфері реалізації фіскальної політки - постійне реформування (перетворення, реорганізацію тощо) центральних органів виконавчої влади, відповідальних за цей напрям роботи держави. Так, окремими недоліками діяльності державних органів влади в сфері реалізації фіскальної політики в Україні слід вважати періодичну зміну формату їх функціонування та нестабільність їх правового статусу. Яскравим прикладом такого положення справ є ситуація з центральним органом виконавчої влади, який безпосередньо відповідальний за реалізацію фіскальної політики в Україні.

Зазначимо, що процес реорганізації Державної фіскальної служби України шляхом їі поділу на Державну податкову службу України та Державну митну службу України проводиться в тісній співпраці з такими поважними міжнародними організаціями, як Міжнародний валютний фонд. Про таку роботу йдеться, зокрема, в Меморандумі співпраці України з Міжнародним валютним фондом [20]. Зазначене свідчить, зокрема, про те, що сьогодні на реалізацію фіскальної політики в Україні значний вплив мають міжнародні організації. Варто відмітити, що встановлення сутності й особливостей такого впливу має значення в аспекті визначення організаційно-правових засад здійснення фіскальної політики в державі в умовах Євроінтеграції. А тому лише зазначимо, що, на нашу думку, кроки, спрямовані на реорганізацію Державної фіскальної служби України шляхом їі поділу на наведені вище центральні органи виконавчої влади, загалом слід розцінювати як позитивні, оскільки одне відомство не може в ефективний спосіб виконувати таку значну кількість завдань і функцій у сфері реалізації фіскальної політики в Україні. Проте, на нашу думку, правові засади діяльності Державної по- 
даткової служби України та Державної митної службо України повинні бути закріпленими не на підзаконному нормативно-правовому рівні, а на рівні окремих законів України, як це здійснено щодо цілого ряду центральних органів виконавчої влади. Успішна реалізація вказаних кроків, спрямованих на вдосконалення діяльності даних органів державної влади в сфері фіскальної політики в Україні та вдосконалення їх правового статусу загалом, позитивно вплине на стабільність їхнього функціонування і як наслідок, значно підвищить ефективність цього напряму роботи держави.

Окрім цього, з огляду на зазначене потребує свого реформування ще один державний орган, відповідальний за реалізацію фіскальної політики в Україні. Йдеться про комітет Верховної Ради України з питань податкової та митної політики, який необхідно реорганізувати шляхом його поділу на комітет Верховної Ради України з питань податкової політики та комітет Верховної Ради України з питань митної політики, що може бути здійснено шляхом внесення відповідних змін до постанови Верховної Ради України «Про перелік, кількісний склад і предмети відання комітетів Верховної Ради України восьмого скликання» від 4 грудня 2012 року № 22-VIII [21] або ж наступних нормативно-правових актів у разі їх прийняття.

Таким чином, аналіз наведеного матеріалу свідчить про те, що першорядними проблемами функціонування органів державної влади в сфеpi реалізації фіскальної політики в Україні, які потребують свого негайного вирішення, є необхідність врегулювання правого статусу таких органів. Сьогодні свого перегляду потребують нормативно-правові акти, на рівні яких закріплено правовий статус основних центральних органів виконавчої влади, які реалізують фіскальну політику за відповідними напрямами. Йдеться, зокрема, про Міністерство фінансів України, Міністерство економічного розвитку і торгівлі України, Державну аудиторську службу України, Державну податкову службу України та Державну митну службу України. Свого реформування потребує й сектор правоохоронного забезпечення реалізації фіскальної політики в Україні.

\section{Jimepamypa}

1. Сарана С.В. Фінансове право України : навч. посібник. Полтава : Полтавський інститут економіки і права Відкритий міжнародний університет розвитку людини «Україна», 2008. 567 с.

2. Положення про Міністерство фінансів України: постанова Кабінету Міністрів України від 20.08.2014 № 375. Офімійний вісник України . 2014. № 69. Ст. 1936.

3. Про Положення про Міністерство фінансів України: указ Президента України від 08.04.2011 № 446/2011. Офіційний вісник України. 2011. № 11. Ст. 610.

4. Питання Міністерства економічного розвитку і торгівлі: постанова Кабінету Міністрів України від
20.08.2014 № 459. Офіційний вісник України. 2014. № 77. Ст. 2183.

5. Про Міністерство економічного розвитку і торгівлі України: указ Президента України від 31.05.2011 № 634/2011. Офіиійний вісник України. 2011. № 41. Ст. 1666 .

6. Про відновлення дії окремих положень Конституції України: закон України від 21.02.2014 № 742-VII. Відомості Верховної Ради України. 2014. № 11. Ст. 143.

7. Конституція України: закон України від 28.06.1996 № 254к/96 BР. Відомості Верховної Ради України. 1996. № 30. Ст. 141.

8. Про центральні органи виконавчої влади: закон України від 17.03.2011 № 3166-VI. Відомості Верховної Ради України. 2011. № 38. Ст. 1696.

9. Про основні засади здійснення державного фінансового контролю в Україні: закон України від 26.01.1993 № 2939-XII. Відомості Верховної Ради України. 1993. № 13. Ст. 110.

10. Про внесення змін до деяких законодавчих актів України щодо діяльності Міністерства фінансів України, Міністерства економічного розвитку і торгівлі України, інших центральних органів виконавчої влади, діяльність яких спрямовується та координується через відповідних міністрів: закон України від 16.10.2012 № 5463-VI. Відомості Верховної Ради України. 2014. № 4. Ст. 61.

11. Про затвердження Положення про Головне контрольно-ревізійне управління України: постанова Кабінету Міністрів України від 27.06.2007 № 884. Офіційний вісник України. 2007. № 48. Ст. 1983.

12. Про оптимізацію системи центральних органів виконавчої влади: указ Президента України від 09.12.2010 № 1085/2010. Офіційний вісник Украӥни. 2010. № 94 . Ст. 3334 .

13. Про Положення про Державну фінансову інспекцію України: указ Президента України від 23.04.2011 № 499/2011. Офіиійний вісник України. 2011. № 31. Ст. 1325 .

14. Питання Державної фінансової інспекції: постанова Кабінету Міністрів України від 07.09.2011 № 968. Офіційний вісник України. 2011. № 71. Ст. 2684.

15. Про затвердження Положення про Державну фінансову інспекцію: постанова Кабінету Міністрів України від 06.04.2014 № 310. Офіційний вісник України. 2014. № 64. Ст. 1764.

16. Про утворення Державної аудиторської служби України: постанова Кабінету Міністрів України від 28.10.2015 № 868. Офіиійний вісник України. 2015. № 87. Ст. 2907.

17. Про затвердження положень про Державну аудиторську службу України: постанова Кабінету Міністрів України від 03.02.2016 № 43. Офіційний вісник України. 2016. № 12. Ст. 506.

18. Про аудит фінансової звітності та аудиторську діяльність: закон України від 21.12.2017 № 2258-VIII. Відомості Верховної Ради України. 2018. № 9. Ст. 50.

19. Пчелін В.Б. Перегляд адміністративних актів органів внутрішніх справ: дис. ... канд. юрид. наук: спец. 12.00.07. Харків, 2011. 190 с.

20. МВФ офіційно оприлюднив меморандум по новій програмі для України // УHIAH. URL: https://www.unian.ua/economics/finance/10401945mvf-oficiyno-oprilyudniv-memorandum-po-noviyprogrami-dlya-ukrajini.html.

21. Про перелік, кількісний склад і предмети відання комітетів Верховної Ради України восьмого скликання: постанова Верховної Ради України від 04.12.2014 № 22-VIII. Відомості Верховної Ради України. 2015. № 1. Ст. 10. 


\section{Анотація}

Соф’̈̈н M. I. Напрями вдосконалення діяльності державних органів у сфері реалізації фіскальної політики в Україні. - Стаття.

У статті на основі аналізу норм чинного законодавства України визначено та охарактеризовано ключові напрями вдосконалення діяльності державних органів у сфері реалізації фіскальної політики в Україні. Метою статті є визначення ключових напрямів вдосконалення діяльності державних органів у сфері реалізації фіскальної політики в Україні. Визначено, що кроки, спрямовані на реорганізацію Державної фіскальної служби України шляхом їі поділу на наведені вище центральні органи виконавчої влади, в цілому слід розцінювати як позитивні, оскільки одне відомство не може в ефективний спосіб виконувати таку значну кількість завдань і функцій у сфері реалізації фіскальної політики в Україні. Проте, на нашу думку, правові засади діяльності Державної податкової служби України та Державної митної служби України повинні бути закріпленими не на підзаконному нормативно-правовому рівні, а на рівні окремих законів України, як це здійснено щодо цілого ряду центральних органів виконавчої влади. 3'ясовано, що правовий статус центрального органу виконавчої влади, відповідального за забезпечення формування та реалізацію діяльності в сфері здійснення фінансового контролю, на нормативно-правовому рівні врегульовано із значними недоліками. Такі недоліки знаходять свій прояв як у значній кількості нормативно-правових актів, на рівні яких закріплено правовий статус даного органу державної влади, так і в назві самого органу, що не відповідає ані його функціональному призначенню, ані змісту його діяльності. Зроблено висновок, що першорядними проблемами функціонування органів державної влади в сфері реалізації фіскальної політики в Україні, які потребують свого негайного вирішення, є необхідність врегулювання правого статусу таких органів. Сьогодні свого перегляду потребують нормативно-правові акти, на рівні яких закріплено правовий статус основних центральних органів виконавчої влади, які реалізують фіскальну політику за відповідними напрямами. Йдеться, зокрема, про Міністерство фінансів України, Міністерство економічного розвитку і торгівлі України, Державну аудиторську службу України, Державну податкову службу України та Державну митну службу України. Свого реформування потребує й сектор правоохоронного забезпечення реалізації фіскальної політики в Україні.
Ключові слова: органи державної влади, напрями вдосконалення, фіскальна політика, правовий статус, вдосконалення.

\section{Summary}

Sofin M. I. Directions of improvement of activity of state bodies in the sphere of implementation of fiscal policy in Ukraine. - Article.

In the article, based on the analysis of the norms of the current legislation of Ukraine, the key directions of improvement of activity of state bodies in the sphere of implementation of fiscal policy in Ukraine are identified and characterized. The purpose of the article is to identify key areas for improving the performance of public authorities in the field of fiscal policy implementation in Ukraine. It is determined that the steps aimed at reorganization of the State Fiscal Service of Ukraine by dividing it into the above central executive bodies should generally be regarded as positive, since a single agency cannot effectively perform such a significant number of tasks and functions in the area of fiscal implementation policy in Ukraine. However, in our opinion, the legal framework for the activity of the State Tax Service of Ukraine and the State Customs Service of Ukraine should be enshrined not at the subordinate regulatory level, but at the level of individual laws of Ukraine, as is done with respect to a number of central executive bodies. It is found that the legal status of the central executive body responsible for ensuring the formation and implementation of activities in the field of financial control at the regulatory level is regulated with significant shortcomings. Such shortcomings are manifested both in a considerable number of legal acts, at the level of which the legal status of a given body of state power is fixed, and in the name of the body itself, which does not correspond to either its functional purpose or the content of its activity. It is concluded that the paramount problems of functioning of public authorities in the field of fiscal policy implementation in Ukraine, which need their immediate solution, is the need to regulate the legal status of such bodies. At present, they need regulatory acts at the level of which the legal status of the main central executive bodies, which implement fiscal policy in the respective areas, is fixed. In this case we are talking about the Ministry of Finance of Ukraine, the Ministry of Economic Development and Trade of Ukraine, the State Audit Service of Ukraine, the State Tax Service of Ukraine and the State Customs Service of Ukraine. The law enforcement sector also needs to reform its implementation of fiscal policy in Ukraine.

Key words: state authorities, directions of perfection, fiscal policy, legal status, improvement. 